\title{
Confusion to Conviction: \\ The Representative, Multilingual Religious Journey of \\ Takakura Tokutarō (1885-1934)
}

\section{J. Nelson JENNINGS*}

Takakura Tokutarō (1885-1934) was a second-generation Protestant Christian theologian in modern Japan. ${ }^{1}$ Born into a merchant family of True Pure Land Buddhist religious heritage, Takakura was formally educated in Meiji Japan's still-new national school system. As a university student he embraced Christianity under the preaching of perhaps Meiji Japan's most influential Protestant church leader, Uemura Masahisa (1857-1925). Takakura then vociferously read English- and German-language theology in coming to his own particular Christian convictions.

Takakura Tokutarō's religious experience, as well as the development of his thought, exemplify the confluence of many streams of the dizzying social-political and religio-philosophical changes flowing through Meiji (1868 -1912), Taishō (1912-1926), and early Shōwa (1926-1989) Japan. This study seeks to examine this important leader's experience and thinking, particularly as he formulated his convictions through the interaction of multiple languages. This analysis of Takakura should cast fresh light on the dynamism inherent to modern Japan's rapid and multifaceted transformation through the fascinating years of the Meiji, Taishō, and early Shōwa Eras.

\section{Inputs}

Japan's late-nineteenth- and early-twentieth-century modernization was spurred along by a proactive reception of various sectors of western societal life. Japanese leaders and the general populace deeply incorporated modern western engineering, education, military, health care, arts and entertainment,

* Rev. J. Nelson Jennings, PhD Mission Pastor and Consultant Onnuri Community Church Seoul, Republic of Korea.

1 The definitive English-language analysis of Takakura's life and thought is J. Nelson Jennings, Theology in Japan: Takakura Tokutaro (1885-1934) (Lanham, Maryland: University Press of America, 2005). Note that birth and death dates will be given only for Japanese figures. 
food, philosophy, clothing, manufacturing, and other areas of life. Meiji Japanese people absorbed these elements into their own lives nationally, locally, and individually.

One area that bled across several others was that of language: English, Dutch, French, Russian, and German studies joined Chinese and Korean (and sixteenth-century, Jesuit-imported Latin and Portuguese) as linguistic conduits for international influences coming into Japanese life and society. These various languages played varying roles related to various fields. Thus, for example, Dutch and German had strong influences in medical terminology, as will be further noted below.

Before proceeding to the roles of western languages for Japanese Christian theology, the often subtle but constantly formative role of Chinese - linguistically and conceptually - needs to be acknowledged. First, Japan developed its writing system by using Chinese characters while adaptively changing the characters' order, syntax, and pronunciation. Second, over the following centuries Chinese terminology and concepts infiltrated various areas of the Japanese language, for example in connection with the influx of certain Buddhist traditions. (Various Chinese importations into Korean and Vietnamese also took place over the centuries, and the ongoing presence of significant Sino-linguistic elements in Japanese, Korean, and Vietnamese must not be forgotten.) Third, several modern western terms and concepts entered Meiji Japanese discourse after first being forged into Chinese characters in eighteenth- and early-nineteenth-century China. Worked out in China first, many key western terms entered Japan in Chinese garb, well-suited or not.

With respect to the development of Japanese Christian theology, all of the western languages listed above - quite often via Chinese after having been adapted into Chinese characters - played important roles. French and Latin fed Japanese Catholic thought, as did Russian for Orthodoxy. With regard to Protestant Christian thought, English, Dutch, and German were particularly vital. These three languages' respective roles, as well as the timing of when those roles were played, corresponded with missionaries' countries of origin and the related destination countries of certain Japanese Christian leaders' studies that they conducted abroad. The timing both of western missionaries' arrivals in Japan and of Japanese Christians studying abroad was directly related to the modernization, industrialization, and international spread of the related western countries. ${ }^{2}$ The timing of Japanese political, intellectual, and

2 Other areas of the world were not as neatly coordinated in terms of missionary reception in relation to country-of-horizon modernization, e.g., in the eighteenth century, before modern Germany was formed in 1871, German-speaking Pietists came to India under the Danish-Halle Mission, plus German-speaking Moravians were serving in the Western Hemisphere. 
economic leaders' selection of sectors of western societal life in order to support Japan's modernization also was a factor.

That meant that English and Dutch came to Japan first (in the 1850s), due to both the long-time international spread of British and Dutch economic (and political) interests plus the newer spread of similar interests of the growing United States of America. German speech and print came a generation later, since the modern nation-state of Germany (and ensuing international influence) did not take shape until 1871 (also the year that the oft-mentioned Iwakura Mission group made its two-year tour of the U.S. and European countries). Hence Japanese Protestant Christian theological development first imbibed English and Dutch theological articulations, then added German theological sources to its menu of intake. Once again, Christian terminology previously translated into or otherwise articulated in Chinese often provided frameworks, patterns, or examples for Japanese use.

It is important to remind ourselves that, while external inputs from China and the West were essential to the process of Japanese Christian formulations, Japanese-language religio-philosophical heritages have been primary for Japanese Christian theological developments. This also holds true - not only in Japan but in any other setting as well - when taking into account the foundational roles for Christian understanding played by the Christian Scriptures and by tradition (the latter to varying degrees, depending on the particular Christian tradition being considered). Indeed, basic for all examples of Christian life, belief, and practice is their rootedness in local contexts, including language, unspoken assumptions, social realities, and local histories. This reality is intertwined with the translatable character of the Christian Scriptures and traditions themselves, foundational as they are. In this sense Christianity's translatable character resembles Buddhist traditions more than Islam with its inherently untranslatable Arabic Qur'an.

As for Takakura Tokutarō, then, he was a Japanese man who thought, felt, prayed, wrestled, believed, preached, wrote, interacted, and came to his religious convictions primarily in Japanese linguistic and religio-philosophical categories. Like others within the rapidly modernizing Japan of the Meiji Era and ensuing years, Takakura absorbed much from outside those categories and was changed accordingly. Fundamentally, however, Takakura's (and Japan's) religio-philosophical substratum continued in ways there were identifiably Japanese. The multilingual journey involved in that fascinating process is what most particularly concerns us here.

\section{Meiji educational developments}

As outlined at the outset, Japan selectively incorporated various currents of western expertise, thought, and culture to advance its own modernization 
project. Pockets of Japanese social and political leaders began to draw on western resources in the 1850 s and 1860 s, when western powers forcibly knocked on Japan's closed doors in order to open up trade relations (and to enhance trade with the much bigger prize, China). As such, these early Japanese incorporations of western influences were haphazard, reactionary, and necessarily out of self-defense. Japan's proactive and intentional reception of the modern West accelerated during the 1870s and 1880s, i.e., during the two decades following the 1868 Meiji Restoration.

Since missionaries from Britain and the United States were the earliest Protestant emissaries to arrive in Japan (in 1859), English language study began to take place in the few port areas to which the missionaries and other foreigners were confined. Interestingly, in Nagasaki the Dutch Reformed American missionary G. F. Verbeck began teaching English (and other subjects, including economics and politics) at the invitation of local officials in $1865,{ }^{3}$ then expanded the languages taught to Dutch, Russian, French, and Chinese. ${ }^{4}$ In 1869 Verbeck moved to the new capital of Tokyo at the new Meiji government's invitation and, incredibly, became head teacher at the centrally important Daigaku Nankō, which eventually (in 1877) became Tokyo University. Under Verbeck's leadership, the four western-style departments of law, literature, science, and medicine were created. Foreign language instruction consisted of English, French, and German, in that order of emphasis. In addition, at the government's request for his consultation Verbeck advised that all medical studies be conducted no longer in Dutch but in German, a vastly influential change that was implemented in $1871 .{ }^{5}$

General summaries of the development of the Meiji education system note that Japanese leaders drew on French and German models in designing their new compulsory, national system. ${ }^{6}$ Summaries also note that foreign language instruction shifted from an emphasis in the 1870s on English by American and British teachers (excepting medical instruction that was uniformly in German) to a growing emphasis throughout the 1880s on German by German instructors. ${ }^{7}$ Also relevant for the 1870 s were the early proliferation, then later reduction (by the financially strapped central government), of both

3 Benjamin Duke, The History of Modern Japanese Education: Constructing the National School System, 1872-1890 (New Brunswick, New Jersey: Rutgers University Press, 2009) 43-44.

4 Nobuhiro Miyoshi, Nihon Kyōiku no Kaikoku: Gaikoku Kyōshi to Kindai Nihon (The National Opening of Japanese Education: Foreign Teachers and Modern Japan) (Tokyo: Fukumura Shuppan, 1986) 35ff.

5 Duke, 2009, 51-55.

6 Cf., e.g., japan-guide.com, "Meiji Period (1868-1912)" http://www.japan-guide.com/ e/e2130.html (accessed January 19, 2016).

7 Cf. Duke, 2009, 235-236, 307ff. 
senmon gakkou ("specialty schools") and foreign language schools. ${ }^{8}$ The 1880s' increased German emphasis came particularly from the leadership of Prime Minister Itō Hirobumi (1841-1909) and his confidant and eventual minister of education, Inoue Kowashi (1843-1895). ${ }^{9}$

Particularly relevant for what the increased German studies starting in the 1880s meant for Christian thinkers is that German instruction moved beyond its confined applicability to medical studies. The exclusive use of German in medicine continued, but such other areas of law and literature also began to be taught in German. ${ }^{10}$ Insofar as Christian leaders came from the ranks of elite students in these other areas and, in correlative fashion, learned German, the connection between German language capabilities and Christian theological development starts to come into slightly sharper focus.

\section{Meiji Protestant leaders}

The first generation of Japanese Protestant Christians slowly began to take shape during the 1860s and early 1870 s, after missionaries' initial arrival in 1859. The first Protestant missionaries, like many that followed them, were English-speaking Americans (Episcopal, Presbyterian, and Reformed). The early American as well as British missionaries gathered groups of young men through teaching them English (and often various branches of western learning, particularly science). The young Japanese men who were attracted to the foreign missionaries and their instruction were of samurai background - but their families had been loyal to the outgoing Tokugawa Shogunate and were thus socio-politically displaced by the revolutionary 1868 Meiji Restoration.

There were three well-known Protestant groups or "bands" that formed in the 1870 s, all led by former samurai who became Christians under the tutelage of American missionary-educators. Those three groups (named after their locations) and their most representative leaders were the Sapporo Band and Uchimura Kanzō (1861-1930), the Yokohama Band and the aforementioned Uemura Masahisa, and the Kumamoto Band and Nishima (sometimes written as "Neesima") Jo (1843-1890). ${ }^{11}$ Uchimura and Nishima went to the

8 Cf. Mori Hideo, Nihon Kyōiku Seidoshi (The History of the Japanese Education System) (Tokyo: Gakugei Tosho, 1984) 29; Ministry of Education, Culture, Sports, Science and Technology, "Higher Education in the Early Meiji Era" http://www. mext.go.jp/b_menu/hakusho/html/others/detail/1317276.htm (accessed January 19, 2016).

9 Duke, 2009, 307ff.

10 Duke, 2009, 308.

11 Arguably Ebina Danjō (1856-1937) was the most long-lasting representative leader of the Kumamoto Band, but the matter relates to timing, especially in relation to Nishima's 1875 initiative to form Doshisha University. 
United States for significant periods of study, and their English language capabilities contributed to their widespread and even international influence.

The first generation of Japanese Protestant leaders were thus linguistically capable to incorporate, and otherwise be familiar with, English-language Christian theology. However, as a whole they were not equipped to deal with the influx of German theology beginning in the mid-1880s. Winfried Spinner of the General Evangelical Protestant Missionary Society (AEPMV), soon joined by Otto Schmiedel, arrived in 1885 . After German residents had been gathered into a mission church, a Japanese church and seminary were founded in Tomisaka (Tokyo) in 1887. "This seminary was, actually, the most important transmitting station of liberal theology to the Japanese churches at the time." 12

\section{Sorting Through German Theology}

Age and circumstances contributed significantly to producing those Meiji Christian leaders who were German-language capable and who embraced Spinner's (and his German colleagues') teachings. For example, Maruyama Michikazu was born in 1869 - about a decade later than the earliest Christian leaders listed above - and his father was the clan physician. In 1883 Maruyama went to Tokyo and for four years learned German and went through pre-medical studies. Having drifted from aspirations for medical practice but taken up by German studies, Maruyama and fellow students such as Minami Hajime were thus primed for meeting Spinner in 1868. Maruyama became enamored with the German shin shingaku ("new theology") that he learned through Spinner et al, thus furthering his ensuing dual ministerial and German instruction career. ${ }^{13}$

To more conservative and English-aware Japanese church leaders such as Uemura Masahisa, the spread of more liberal German theological ideas was both disconcerting and linguistically impenetrable. Uemura thus took issue in the early 1890s with Kanamori Michitomo (1857-1945), a leading exponent of the new, liberal theology imported via German channels. In 1891 Kanamori produced his book The Present and Future of Christianity in

12 Spinner's 1885 arrival is universally noted in surveys of Japanese Christian history. Here I have cited Mira Sonntag, "The 'German East Asia Mission' in Japan - Past and Present" Kyodan Newsletter, December 1, 2009, http://uccj.org/knl/4396.html (accessed January 19, 2016).

13 Kamimura Naoki, Kindai Nihon no Doitsugo Gakusha (German Scholars in Modern Japan) (Nagano-ken, Suwa-shi: Chōeisha, 2008) 381-387. (Thanks to Haruko Nakamura for referring me to this book, located in the stacks of Yale's Sterling Memorial Library.) 
Japan. ${ }^{14}$ The next year he published his free translation of Otto Pfleiderer's 1878 Religionsphilosophie auf geschichtlichter Grundlage. ${ }^{15}$ Kanamori advocated a religion of truth and life achieved through harmonious union between God and human beings, associated with a discarding of the primitive teachings of the Bible as well as such traditional Christian theological claims as the divinity of Christ. Hence "From Uemura's point of view, Kanamori appeared to be a man who had adopted strange ideas imported from foreign theology."16 (Interestingly, however, such linguistic-theological differences did not prevent some Christian leaders from offering unified political support of Uchimura Kanzō after the famous 1891 lesé majesté incident, when Uchimura did not bow before a public display of the newly promulgated Rescript on Education. ${ }^{17}$ )

One of Uemura's challenges, however, was that he and other like-minded Japanese Christian acquaintances were incapable of understanding the German expression of theology upon which Kanamori was drawing. After forming a new seminary in 1904, Uemura had assembled at least two Japanese colleagues familiar with German thought, the philosopher Hatano Seiichi (1877-1950) and historian Ishihara Ken (1882-1976). Even so, imagine Uemura's delight and relief when a young German-capable student named Takakura Tokutarō entered the small seminary in 1908. Takakura had learned German in high school in the early 1900s, which he continued to use in his legal studies at the Tokyo Imperial University before leaving after two years to pursue theological studies under Uemura, through whose preaching Takakura had believed in Jesus and been baptized in December, 1906. So as to explore the German background of what had become Japanese liberal theology, Uemura had Takakura launch into reading Friedrich Schleiermacher,

14 Nihon genkon no Kirisutokyō narabini shōrai no Kirisutokyō (Tokyo: Keiseisha) 1891.

15 Summaries of Meiji Christianity and theology note the "free" nature of Kanamori's translation, thus indicating a lack of German-language fluency. How Kanamori acquired his German-language familiarity that he had is unclear, although his relatively early birth in 1857 (in comparison to Maruyama, for example, who was born in 1869) no doubt is relevant to the greater hurdles he had to overcome in learning German.

16 Akio Dohi, "The First Generation: Christian Leaders in the First Period," in Yasuo Furuya, ed. and trans., A History of Japanese Theology (Grand Rapids, Michigan: William B. Eerdmans Co., 1997) 22-24.

17 Cf. Yoshiya Abe, "Religious Freedom under the Meiji Constitution," Contemporary Religions in Japan Vol.9, No. 4 (Dec., 1968), pp. 268-338. I accessed the section "III. Religious Freedom and the Imperial Rescript on Education" at http://nirc. nanzan-u.ac.jp/nfile/3222 (accessed January 19, 2016); note particularly pp. 195-196 (where Maruyama's first name is incorrectly, I believe, listed as "Tsūichi," although the Chinese characters could be read that way). Cf. as well Kamimura, 385-386. 
Albrecht Ritschl, and other influential nineteenth-century German theologians. ${ }^{18}$

By his own testimony, Takakura was at first enamored with Schleiermacher and then Ritschl. However, as he progressed in his own thinking while pastoring and then studying in Britain (1921-1924), Takakura came to his own strong conviction of Fukuinteki Kirisutokyo ("Evangelical Christianity"). Takakura firmly believed in the centrality of the Bible, the Cross of Jesus Christ, and European Reformers such as John Calvin and Martin Luther. As such he stridently criticized both the "liberal theology" and "social Christianity" that had spread widely in Japanese Christian circles by the time of Takakura's widest influence in the late 1920s. ${ }^{19}$

As a student of Uemura but also as a unique Japanese theologian, Takakura digested both Anglo-Saxon and German theology in such a way that resulted in an understanding that was vastly different from that of Kanamori Michitomo. Takakura's German-language ability was stronger than Kanamori's, and presumably Takakura had more concentrated opportunities to read and study German theology. Due to these and many other factors, Takakura and Kanamori represent two different ways in which early Japanese Protestant leaders absorbed German-language theology and then reproduced that theology as Japanese Christian thinkers. ${ }^{20}$

\section{Takakura's Fukuinteki Kirisutokȳ}

The journey that Takakura took to arrive at his convictions about Fukuinteki Kirisutokyō ("Evangelical Christianity") was - like for many of his Japanese contemporaries - a multilingual one. As noted earlier, the thoroughly Japanese-speaking Takakura began to learn German in high school. It was as a university student that Takakura heard the Christian message preached through Uemura Masahisa. Takakura believed, per his own testimony, in order to solve the "problem of the self." Working through that existential angst was deeply personal for Takakura as well as indicative of other younger Japanese intellectuals of his day. ${ }^{21}$

Soon after his conversion to Christianity, Takakura left his university legal studies to study theology in Uemura's new and small seminary in Tokyo. Part of what Takakura was requested to study was German theological works, especially since they were largely undecipherable to Uemura and other

18 Jennings, 2005, 10-14, 157-158.

19 Cf. Jennings, 2005.

20 It was in the mid-1920s, then especially in the early 1930s, that German dialectical theology, especially in its Barthian form, swept through much of the Japanese Protestant theological world.

21 Cf., for example, Jennings, 2005, 263-265. 
mentors of Uemura's generation. That taste of German theology piqued Takakura's quest for wider study, so even during a decade of pastoring and otherwise living outside of academic life (and functioning primarily in Japanese) Takakura read and wrote about several western theological works and biographies. ${ }^{22}$ In 1921, at the age of 36, Takakura embarked on almost three years of theological study in Britain.

Takakura's time in Edinburgh, Oxford, and Cambridge was focused on course work but most especially on reading. Correspondence from Japan maintained his attention on people's concerns back home. Primarily, however, Takakura gave himself to living abroad, to learning English, and particularly to reading a wide range of English- and German-language theological works. ${ }^{23}$ Takakura was all the while processing what he was learning in Japanese, facing the daunting challenge of translating concepts and emphases shaped in Western intellectual worlds that did not lend themselves well to smooth transition into alien settings.

Not long after returning to Japan in 1924, Takakura faced the sorrow of the death of Uemura Masahisa, Takakura's and many others' mentor and inspirational model. Takakura also then faced the challenge of assuming the imposing mantle of Uemura's far-reaching ecclesiastical and theological leadership. It was in the midst of such stretching circumstances that Takakura came to a place of clearly and boldly articulating his convictions about Fukuinteki Kirisutokyo, culminating in his 1927 book of that title. Takakura continued to express those same convictions until the deterioration of his health and untimely death in 1934. Takakura's published writings, especially Fukuinteki Kirisutokyo, carried his influence widely to Japanese church leaders and theological students well into the 1950s.

The process of how Takakura came to his convictions included the interaction of a number of elements and forces. Overall, that process can perhaps best be described as Takakura's particular translation of the expressions of Christianity that he received through both Uemura Masahisa (plus other Meiji Christian conduits) and western thinkers. These expressions came into both his dynamic setting of a modernizing Japan and his own life that had grown out of his family's non-samurai (social) and True Pure Land Buddhist (religious) heritages. The remainder of this study will example the various components of Takakura's translation process as just listed.

First, the manner in which Takakura Tokutaro came to his convictions was his unique process. To be sure, he shared (and in identifiable ways represented) many of the same traits and challenges of his Japanese contem-

22 Ibid., 157-158.

23 Ibid., 159-187. 
poraries. Also, insofar as Takakura's convictions were specifically Christian, his conversion and development resembled those of others who convert and develop in their beliefs and lives in relationship to the same Christian Creator-Redeemer. Even so, this man worked through his life uniquely, and the manner in which he did so demonstrates creativity, ingenuity, courage, and resolve.

Takakura's uniqueness is important to emphasize in light of the ways he has commonly been portrayed. Many have seen his thought as passively developing along a line of influences that came to him, in particular a series of Western thinkers beginning at Friedrich Schleiermacher and ending at P.T. Forsyth and Emil Brunner. As such, Takakura's dual role in Protestant Japanese theological development has been seen merely to have faithfully conveyed Uemura Masahisa's theology to the next generation and the justlisted western theologians' emphases to Japanese theological students in a way that prepared the way for the overwhelming influence that Karl Barth's theology had in Japan beginning in the 1930s. Contrary to those common analyses, however, is this study's understanding, and forthcoming demonstration, that Takakura was much more creative and unique than simply a conveyer of other Christian thinkers' emphases.

With respect to Uemura, on the one hand Takakura did in fact pass on his mentor's Bible-based and Christocentric teaching to the next generation. He did this through succeeding his mentor in leading the seminary that Uemura had founded, as well as through his many writings and perhaps most prominently through his preaching, media similarly used by Uemura. On the other hand, contrary to common expectations Takakura did not succeed Uemura in pastoring the Fujimicho Church in Tokyo, since there were enough church members who saw Takakura as different from Uemura. In particular, Takakura exhibited more spiritually interior concerns than had the institution-building Uemura. Takakura's message was also even more Crosscentered than Uemura's overriding stress on Jesus's divinity; one could say that Takakura focused more on Christ's atoning work and Uemura more on Christ's position as the divine Son of God.

Takakura's distinctive differences from Uemura can of course be attributed to the generational gap between the two. Not unrelated is how Uemura, like other first-generation Meiji Protestant leaders, came not only from samurai lineage but from samurai families that had been loyal to the Tokugawa Shogunate overthrown by the new Meiji oligarchy from southwest Japan. Uemura and other Meiji Christian leaders, e.g., Uchimura Kanzo and Ebina Danjo, thus envisioned a rebuilt Japan that was to be renewed through the purifying and uplifting influence of Christianity. Takakura, however, did not have that same instinctive sense of public, national responsibility, since his 
background was not samurai but of the merchant class. Furthermore, Takakura's ingrained Jodo Shinshu religious instincts would have pulled him to more spiritually interior matters than to Uemura's public focus. How Takakura's religious heritage shaped his translation of the forms of Christianity that came to him will be further examined below.

The plethora of western thinkers that Takakura encountered is difficult to summarize in this relatively brief study. As noted earlier, throughout his adult life Takakura voraciously read a wide spectrum of English-language (mostly Scottish and English) and German-language theologians. The depth of Takakura's appreciation for the Western authors he read is clear simply from the bibliography of Fukuinteki Kirisutokyo, consisting almost exclusively of English and German references. That book, as well as other writings, is liberally sprinkled with phoneticized Western terms, demonstrating how Takakura was constantly importing English and German concepts and words he had encountered into his explanations to Japanese readers.

It is important to note that Takakura did not simply passively receive whatever western thinkers were presented to him. This is especially clear during the year Takakura spent in Oxford, which was his middle period in the United Kingdom. ${ }^{24}$ Per his own description, Takakura eschewed attending classes at Mansfield College where he was enrolled, but instead gave himself to "only reading, while surrounded by the books I had bought." 25 He selected which books he read, guided by concerns he had personally for Christianity's roles in Japan. He could thus use several Anglican thinkers, Ernst Troeltsch, Baron Friedrich von Hugel, and most especially P. T. Forsyth for moving toward what for him was the deepest need he had, namely for kakushin or "certainty" of faith.

There was no more basic or important theme for Takakura, both personally and as a theologian, as kakushin. The concern for certainty arises throughout his writings. As Takakura himself put it, "Faith is most sensitive to the certainty of its object." 26 Also, "The most important thing for religious consciousness is God's objective certainty." The importance for Takakura of kakushin can be seen in the manner in which he discusses and argues for any number of points because they contribute to having kakushin:

- Why the objective revelation and "Word" of the Bible is to be enbraced;

- Why God is the Creator;

24 For a more detailed account of what is summarized here, see Jennings, 2005, 164177.

25 Jennings, 2005, 164.

26 Original references for this section can be found at Jennings, 2005, 351. All emphases are original. 
- Why the Cross is the final eschatological solution to sin;

- Why God's faithfulness to forgive and purify sin is to be seen in the Christ's Cross and shed blood;

- Why grace alone gives salvation;

- Why the "faith of election" should be believed;

- Why faith is God's work;

- Why God's "eternal administration" is to be trusted;

- Why spectulative reason is inadequate;

- Why the "inner necessity" of Jesus and Paul is to be treaured;

- Why prayer is important;

- Why prayer is to be done in faith alone;

- Why prayer is to be done with the help of the Holy Spirit.

More than to rational argument or authoritative support from Scripture and recognized authors, Takakura appeals to the giving of certainty and conviction as the single most decisive factor for accepting most any point he commends to others.

Furthermore for Takakura, Reformation, evangelical, biblical Christianity was fundamentally different from rationalistic, pietistic, and Roman Catholic Christianity in leading to "eschatological certainty," in having "conviction." Takakura appeals to "eternal" reality because that is unmovable, "certain" reality. Even though Takakura's understanding of the "most certain reality" shifts within his developing thought from the "self" to "God," the very phrase "certain reality" indicates the union for Takakura of the "certain" and the "real." The conviction-experience of the awareness of God's grace in the Cross is the true and real certainty.

Why kakushin was so decisive and important for Takakura is difficult if not impossible to know. One central explanation comes out of his Jodo Shinshu religious heritage. ${ }^{27}$ That heritage was Takakura's "ontological past" that demanded his attention as a Christian convert. A Jodo Shinshu mindset cultivated in Takakura at his grandmother's knee would have included a posture of introverted focus on direct, immediate experience. It would have also included a pietistic bent toward trusting in an "Other power" versus "self power," or one's own ability to achieve salvation. Encounters with Nishida Kitaro and other Mahayana thinkers would have cultivated in Takakura a "subjectivity-only" mindset that is not entrapped within a "subject-object" dichotomy. It is thus only to be expected that Takakura would later stress the importance of becoming "self-aware," or to jikaku matters of faith and ultimate commitment.

27 Jennings, 2005, 299-305. 
Related is Takakura's long-time struggle of "solving the problem of the self," which he gave as the primary motivation for his conversion to Christianity. ${ }^{28}$ Per his own descriptions, Takakura was looking for answers to such questions as "What properly speaking is the 'self'? What can one do to free, fulfill, and thoroughly realize it?" As a young adult Takakura "thought that only the self alone had any authority. I came to the desperate state of defying and refusing anything and everything that sought to shackle or deny the self." After awakening to the self's condition as thoroughly egostistical, Paul later "collided" with the Apostle Paul's words in the book of Romans, words that "deeply penetrated [his] heart." Soon thereafter, Takakura experienced an ontological-epistemological merging of his own "self" and the ultimate "Self" or, in biblical language (specifically Paul's words in Galatians 2:20), Takakura's self or ego died and Christ lived in Takakura.

Putting the matter in a multilingual framework, Biblical language, incorporated by the Japanese Takakura directly and through German- and English-speaking Protestant thinkers, led Takakura into becoming self-aware of the epistemological-ontological merging of the self/Self. ${ }^{29}$

This study's necessarily abbreviated sketch of how Takakura incorporated multilingual (and interreligious) inputs would be remiss if it omitted at least brief descriptions of some of the conceptual pairs that Takakura employed. ${ }^{30}$ He used "worldview" pairs, both antithetical (e.g., scientific, materialism versus a view embracing freedom and value; Buddhistic, atheistic, pessimistic fatalism versus a spirit of responsibility and self-sacrifice) and complementary (e.g., transcendent-immanent, dynamic-static, Hebraic-Hellenistic, visibleinvisible, eternal-historical). Among the several eternal-time pairs Takakura used was a geometric pair of a point within history and a line throughout history. In particular, all of linear history is redeemed by Christ, while the punctiliar act of God in Christ is the "condensation," the "apex," the "center" of history.

Perhaps most puzzling and surprising of Takakura's conceptual pairs is that of "objective" and "subjective." For Takakura, those terms kyakkan(-teki) and shukan(-teki) - both of Chinese derivation - refer primarily to "public" or "corporate" versus "private" or "individual." The normally expected English meanings of "exterior" versus "interior" are not totally excluded; it is just that "public-corporate" and "private-individual" are the meanings Takakura employs with those terms.

There are subtle intricacies involved with discussing here the interrelation-

28 Jennings, 2005, 305-311.

29 Jennings, 2005, 351-352.

30 Jennings 2005, 340-347. 
ships between the multiple languages involved, adjoining conceptual meanings, and Takakura's religious heritage. In short, Takakura's "subjectivityonly" instincts enabled him to stress the importance of kyakkanteki faith as well as personal experience of the Church's faith in the atoning Cross of Christ. For Takakura, his self/Self-awareness or jikaku overcame historical, ontological, psychological, and gaps between the Cross and his own faith, or between the religious experience of the Apostle Paul and Takakura's faith. For Takakura, kyakkanteki or "public-corporate" faith is what gives kakushin in one's soul. That was essentially Takakura's unique incorporation and translation of multilingual realities into his Jodo Shinshu shaped world.

\section{Conclusion}

In all of his unique and particular ways of manifesting what for him was the certainty and truth of Fukuinteki Kirisutokyo, Takakura Tokutaro also exhibited some of the common trends of his historical period. Linguistically, he flowed in the Meiji stream of shifting from Chinese to European influences. ${ }^{31}$ In particular, the mainstream Meiji style of kanbun kundoku, whereby Chinese texts had been rearranged in Japanese syntactical order and with Japanese inflectional suffixes added, gradually gave way to styles that incorporated European-influenced phraseology. Takakura certainly included such European-influenced style in his writing.

Moreover, Takakura used Chinese terms that had recently been invented, or at least had been given new meanings, in order to incorporate Western concepts and words. Some of the best known new terms were shakai, kojin, kindai, sonzai, kenri, and jiyuu. ${ }^{32}$ No doubt such important terms for Takakura as kyakkan and shukan fell among that same category as well.

Takakura also exemplified many of the struggles and challenges of his contemporaries in Meiji, Taisho, and early Showa Japan. His central wrestling with the "problem of the self" was shared by literary and other public figures. The dizzying speed of Japan's modernization affected everyone, including of course the Christian theologian and pastor Takakura Tokutaro.

The multiple languages involved in Japan's modernization, and in Takakura's coming to his assured religious convictions, played vitally important roles. Those roles do not provide the sole explanation for his Takakara and others struggled and changed, but they tell us a great deal of the fascinating process through which the Japanese of Meiji, Taisho, and early Showa struggled to find their place in the modern world. Studying figures such as

31 Nano Sato-Rossberg and Judy Wakabayashi, eds., Translation and Translation Studies in the Japanese Context

32 Akira Yanabu, Honyakugo Seiritsu Jijo (Tokyo: Iwanami Shoten, 1982) ii. 
Takakura Tokutaro sheds helpful light on a fascinating and clearly vital period of world history. 